\title{
STEAM teaching professional development works: effects on students' creativity and motivation
}

\author{
Cathérine Conradty ${ }^{*}$ (D) and Franz Xaver Bogner
}

\author{
* Correspondence: catherine. \\ conradty@uni-bayreuth.de \\ University of Bayreuth, Z-MNU \\ (Centre of Maths and Science \\ Education), Bayreuth, Germany
}

\begin{abstract}
A promising way to bring STEAM (STEM enriched with Arts) into classrooms is the Professional Development (PD) path. Its main difference to a usual PD lies in the introduction of creativity with its social skills rather than just on cognitive learning, and thus in STEAM teaching, teachers need training in new ways of teaching. In order to establish STEAM in everyday school life, an effective PD is required to go beyond onetime interventions, which seldom work sustainably. After our course schedule, the participating teachers were supposed to apply their expertise in their next school year's classroom. The provided material ensured the teachers to work regularly with STEAM, and as the involved teachers were supposed to recapitulate and consolidate their STEA M skills in their classroom work. Following the PD goals, the students $(N=550)$ of the participating teachers were monitored for scientific motivation and creativity in order to examine the PD effects. For the analysis, we calculated canonical correlations to confirm the association between creativity and motivation. The structural equation model (SEM) confirmed the model that with STEAM creativity has a positive effect on motivation: A long-term PD that is integrated into school life is an appropriate sociocultural sustainability entry to promote creativity in classrooms. Through creativity, apparently, students' self-efficacy increase. In conclusion, integrating creativity into education via PD works and may provide a promising channel to multiplication into further science classrooms, which is discussed in the conclusions.

Keywords: Creativity, Science-arts collaboration, Motivation: self-efficacy, STEM education, STEAM (enriched with arts), inquiry-based science education, Science classroom, Canonical correlation, Structural equation model SEM
\end{abstract}

\section{Introduction}

The keyword "STEAM" refers to the integration of arts (A) and creativity in the classical STEM teaching (Science, Technology, Engineering and Mathematics). It is supposed to enrich science classrooms with creative interventions and by that way to counteract the low reputation of science teaching as abstract, difficult or even boring (Bennett \& Hogarth, 2009; Henriksen, 2014). STEAM is assumed to enhance science lessons by making them more attractive, although creativity is in general associated more with artists than with engineers. Additionally, scientific thinking has been

(c) The Author(s). 2020 Open Access This article is licensed under a Creative Commons Attribution 4.0 International License, which permits use, sharing, adaptation, distribution and reproduction in any medium or format, as long as you give appropriate credit to the original author(s) and the source, provide a link to the Creative Commons licence, and indicate if changes were made. The images or other third party material in this article are included in the article's Creative Commons licence, unless indicated otherwise in a credit line to the material. If material is not included in the article's Creative Commons licence and your intended use is not permitted by statutory regulation or exceeds the permitted use, you will need to obtain permission directly from the copyright holder. To view a copy of this licence, visit http://creativecommons.org/licenses/by/4.0/. 
recognised to require creative ability, which is not based solely on talent (HolmHadulla, 2010), but must be preserved and trained (de Bono, 1990). STEM curricula may benefit from the integration of arts or creative aspects, thus encouraging creative solutions rather than to get ready solutions presented (Henriksen, 2014). In many countries, it is already the case that syllabi recommend STEAM teaching. Professional Development initiatives should help teaching staff to stimulate structural change. What makes creativity so attractive that an educational structural change is demanded? What can teachers achieve in the conflict between the cognitive learning goals of curricula and new demands for creativity? How effective is Professional Development? Given these questions, the present study was built up.

\section{What makes creativity so attractive to strive for a fundamental change in STEM lessons for its integration?}

STEM subjects often have a tattered reputation as they are regarded as stressful, sometimes even frightening. Learning difficulties in that subjects often might originate poor self-efficacy levels (Conradty \& Bogner, 2016; Epstein \& Fischer, 2017; Schumm \& Bogner, 2016). Anxiety comprises feelings of tension and discomfort that might prevent a student from using their entire potential and could cause negative attitudes toward science (Tooke \& Lindstrom, 1998). This vicious circle may cause negative attitudes towards individual abilities (Pajares, 2016) leading to barriers in STEM education by restricting problem-solving skills, e.g. (Pitsia, Biggart, \& Karakolidis, 2017). Even the missing women might not be a natural effect due to gender-specific talent and interests but caused by low self-efficacy of girls. A role-model-based conflict prevents girls from pursuing a science career (Reddy, Menon, \& Thattil, 2018). Considering to serve both genders, in the face of female scientists, girls can rethink their role model (Reddy, Brothers, Quave, \& Chen, 2019).

Self-efficacy, defined as judgement or assessment of one's capabilities to perform a particular given task successfully (Bandura, 2012), is an element of intrinsic motivation (Deci, Schwartz, Sheinman, \& Ryan, 1981). It has been highlighted as an essential predictor of general academic performance (Ferla, Valcke, \& Cai, 2009). Thereby, selfefficacy is regarded as a major trigger for purposeful behaviour and the perseverance to achieve set goals, which usually results in good marks - or in the long run to a science career (Özcan \& Eren Gümüş, 2019). Self-efficacy constitutes a leading non-cognitive construct (Özcan \& Eren Gümüş, 2019) affecting variables such as behaviour via feeling, thinking, acting or self-motivating (Bandura, 2012). The latter is regarded as an inner drive to direct an individual's behaviour toward the fulfilment of a goal. Both creativity and self-efficacy need a social environment of openness, where learners can experiment to explore their abilities and efficacies (Csikszentmihalyi, 2010). Self-efficacy seems to play a key role in both developing a healthy, productive personality and motivating people to learn. Creativity in STEAM revealed promising results in current research fostering motivation of students (Chappell et al., 2019; Conradty \& Bogner, 2020b; Hetherington et al., 2020). In search of a solution, STEM in combination with Arts is discussed to help to bridge these barriers (Henriksen, 2014): STEAM could improve STEM's reputation, reintroducing creativity in the form of art. A better reputation could potentially regain students' trust by reducing stress and anxiety. 
STEM curricula, in their new format of STEAM education, may benefit from the integration of arts and creative aspects to encourage creative solutions (Henriksen, 2014). Creativity, within the structural model of intelligence, is still defined as an unprecedented and effective way to solve problems (Csikszentmihalyi, 2010). According to this model, creative individuals need appropriate, appreciative environments.

Creativity seems to be one of the most difficult psychological constructs to explain (Corazza, 2016). If creativity is lacking, however, its effects and importance become apparent. Above all, creative thinking is required to solve problems. The more complex the problems are, the more creativity is needed. For this reason, creativity was recognised as a key skill for the twenty-first century (Wagner, 2010). Nevertheless, school environments are accused of discouraging children for more creativity, although school could also very well encourage creativity (Barbot, Besançon, \& Lubart, 2015).

For creativity, attitude is regarded as essential. Both the creative person and his/her social environment need a great deal of openness to the process of generating ideas. Urban's personality traits of creativity suggest that school as psychosocial surrounding should foster creative thinking (Urban, 1991): From a psychological point of view, fluid thinking and association are essential, which, for instance, could be exercised with mind mapping (Novak \& Cañas, 2006).

Creativity is supposed to keep a balance between fear and boredom, which may explain the evolutionary advantage of creativity (Csikszentmihalyi, 2000): When people faced a new problem, they experimented with solutions, maintaining the balance between mindfulness and risk in order to survive. With this evolutionary background in mind, it becomes evident that the archetype of human creativity is the problem-solving ability that needs security for its unfolding. Since gender differences in creativity are found only in some but not all cultures (e.g. Archer et al., 2013; Matud, Rodríguez, \& Grande, 2007; Shen, Liu, Shi, \& Yuan, 2015), school education seems to have a decisive influence (Csikszentmihalyi, 2000). The integration of creativity into STEM education (STEAM) may have several opportunities. On the one hand, STEAM may educate students to become successful scientists, as they need to develop creative thinking skills. On the other hand, creativity is regarded as closely related to motivation, as creative subjects report a process of discovery as the most enjoyable experience (Csikszentmihalyi, 2000), even though the interrelation and impact of creativity on learning success and motivation are not yet understood. STEAM might make science more attractive, increase motivation and encourage creative, critical thinking about real-world problems. Bridging "boring knowledge" with creative brainwork may help to overcome the existing "creative gap" in STEM (Runco, Acar, \& Cayirdag, 2017). When students experience the creative beauty of science, they might feel more encouraged to pursue a science career. The intensely emotional impact and enthusiasm children may experience when dealing with art could be transferred to the sciences when students learn with STEAM. (Runco et al., 2017). As motivation and cognitive achievement correlate strongly even cognitive success profits from STEAM (Conradty \& Bogner, 2019). These findings suggest what qualities are needed in STEM: "Flow" is a mental state of creativity, in which a person performs an activity while fully immersed in a feeling of energised focus, full involvement, and enjoyment (Csikszentmihalyi, 2000). It is perceived as a high intrinsic motivation, particularly experienced at young ages. Unfortunately, later in 
adolescence, it tends to disappear, perhaps due to a one-sided education based on knowledge-based, logical sense-making patterns (Csikszentmihalyi, 2000).

Creativity needs a secure environment offering space for self-regulation and selfresponsibility to support self-efficacy, whereas these as part of a competence promoting learning environment are well known to foster learning. The effects of guided versus unguided learning have been well described, as have the level of free choice and individual responsibility in open inquiry learning settings, leading to higher long-term knowledge levels, to less tension and better-perceived competences (Sadeh \& Zion, 2009). Franklin et al. (2015) described open inquiry-based learning as an option to promote a deeper understanding of complex scientific issues: Guided inquiry seems to provide the best approach to effective (short-term) learning, while open inquiry seems to offer enhanced opportunities for cognitive development and scientific reasoning (Schmid \& Bogner, 2015). Guided learning tends to be without sustainability with short-term effects on knowledge and interest whereas unguided self-regulated learning supports self-efficacy resulting in sustain longterm knowledge acquisition (Conradty \& Bogner, 2016).

\section{Teacher professional training}

Teacher PD are processes and activities designed to enhance the professional knowledge, skills and attitudes of educators so that they might, in turn, improve the learning of students (Guskey, 2003). They are of particular importance when not focusing on the subject, but methodology, because teachers are supposed to transform practices with twenty-first-century skills to meet student needs (Yue, 2019). Flexible teaching practice is needed that makes teachers more readily to adapt to the ecological, social, and economic challenges that humanity currently faces (Hensley, 2018). Most of the current PD activities can be characterised as traditional forms of PD. Traditional forms refer to the way PD was organised for the last decades: mainly through lectures, 1-day workshops, seminars and conferences, which were not situated at the workplace; teachers played a passive role during the PD, and the content was not adjusted to the problems and issues of the daily teaching practice (van Veen, Zwart, \& Meirink, 2012). Innovative forms refer to all those interventions in which teachers do play an active role, and the issues in their teaching practice determine the content. In general, there is a strong focus on the subject matter, active and inquiry-oriented learning and professional learning communities.

Nevertheless, elements of the traditional forms of PD are still in use. The innovative PDs are rarely offered but are considered more promising and better than traditional, even although empirical evidence for this assumption is still missing (van Veen et al., 2012). When, however, is PD effective? One potential reason for this lack of evidence relating to what works is the discussion about what is considered to be evident. Others, while supporting the evidence-based approach, point to the risk of constructing lists of what works because it might "provide yet another set of recommendations devoid of underlying theory and messages" (Hattie, 2010), p.3) or neglecting the specific features of the context.

A significant point for the success of PD is time. "Research shows that intellectual and pedagogical change requires PD activities to be of sufficient duration (e.g. one day 
or one semester)" (Desimone, 2009). Short-term intervention of at least $14 \mathrm{~h}$ (Yoon, Duncan, Lee, Scarloss, \& Shapley, 2007) to $20 \mathrm{~h}$ (Desimone, 2009) of training are sufficient. For a behavioural change of teachers, a minimum of $80 \mathrm{~h}$ of training is estimated (Supovitz \& Turner, 2000). A different aspect of duration is the sustainability of the intervention (Desimone, 2009; Yoon et al., 2007). One-shot, short-term interventions might be less effective than long-term interventions combined with enduring follow-up support, such as follow-up interventions, permanent support of group collaboration and ongoing facilitation of teacher learning). Some studies point to the importance of a learning community (Desimone, 2009; Ermeling, 2010). Other studies emphasise the importance of a sufficient amount of time (Buczynski \& Hansen, 2010). However, they seldom elaborate on the implications of such conditions for the daily schedule of a school and teachers' workload (van Veen et al., 2012).

Teachers always suffer from a high workload with a tight time budget. It is unrealistic for teachers to spend a too long time on PD. Therefore, short training can be more promising if the everyday reality of the teacher is taken into account. Firstly, the short amount of time: Teacher training can usually not take long. If the material is conveyed in the same form as the teachers will later teach it, the form corresponds to the learning objective, and the form of teaching is intuitively conveyed with the material. The second everyday problem for teachers is the workload: If the training provides material that can (and should) be used weekly in the current school year, this also encourages the weekly renewed practice of the teacher training. Assuming that the success of a PD lies in the school implementation in addition to the assessment and satisfaction of the teachers, it is of particular interest how students develop with STEAM education. As STEAM education intends to foster motivation and creativity skills, we evaluate these factors. Desimone's (Desimone, 2009) conceptual model demonstrates interactive, nonrecursive relationships between (A) the critical features of $\mathrm{PD}$, (B) teacher knowledge and beliefs, $(C)$ classroom practice and (D) student outcomes (see Fig. 1). The relationships between these elements are not linear per se. Change in teaching behaviour can be caused as much by a change in teacher knowledge as a change in student behaviour (Guskey \& Sparks, 2004). 'Thus, our design is to measure the effect of the PD on teachers' behaviour in the changes in their students' motivation and creativity.

\section{The STEAM initiative of CREATIONS}

Our CREATIONS project developed about 100 modules for science classrooms (Conradty \& Bogner, 2020b) Most of them were supported by PD courses in order to prepare involved teachers appropriately for implementing them into their classrooms. In

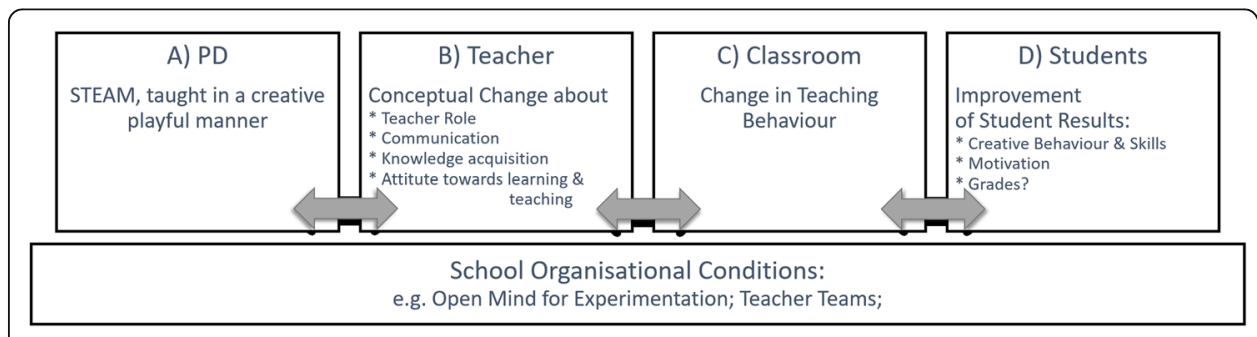

Fig. 1 Conceptual Model for Studying the Effects of PD, adapted according to Desimone, 2009 
shadowing them, they proved effective in supporting motivation and creative ability (Conradty \& Bogner, 2020b). To ensure STEAM in everyday school life in promoting contemporary science teaching, CREATIONS included teacher PD courses from longterm projects, summer schools and short-term intervention in schools and out of school.

To indirectly verify the sustainability of STEAM teacher training, we assessed students' motivation and creativity of classes, whose teachers participated in the PD. Two arrangements were taken to ensure that teachers were able to integrate their training neatly into the classroom: First, they were given the complete teaching material on the topic for the whole school year. Second, the chosen subject of training with Particle Physics was not part of the regular primary school curriculum and thus too demanding without external assistance. For this reason, teachers were considered without any competing teaching concept as novices for the selected STEAM intervention. Teachers' inexperience ensured that they carried out the lessons as they have been taught within the PD action.

Our research hypothesis was that the PD design results in increasing students' selfefficacy through experienced creativity, which results in increasing motivation. Therefore, the objectives of our longitudinal survey were: (i) Did the lessons following the PD affect creativity and motivation? (ii) Is there are a gender effect in science career motivation, self-efficacy or creativity? Can STEAM engage girls for the sciences? (iii) How are creativity and motivation related to each other?

\section{Methodology}

Participants

Out of a total sample of 550 fourth graders, a subsample of 207 completed both tests of a pre-post-schedule (aged 9-13 years, $\mathrm{M}=10.52 \pm .74 ; 45.8 \%$ females). Their regular classroom teacher taught their students after teachers' participated in a PD course at CERN (Conseil Européen pour la Recherche Nucléaire; European Organization for Nuclear Research).

\section{Professional development for primary teachers}

The course in question included the complete teaching material of a school year in particle physics, named "Playing with Protons" (PwP). By working through the modules, the teacher learned both the subject matter and the creative way of STEAM teaching (Alexopoulos, Pavlidou, \& Cherouvis, 2019). Since particle physics is not currently part of the primary school syllabus, the participating teachers were novices with respect to teaching this subject. In this way, the new STEAM concepts did not compete with old teaching concepts, and this ensured that the teachers followed the creative guide, using only the prepared teaching material. While working through the modules, teachers accustomed to creative STEAM teaching as they were to imitate it in their lessons (Chamaeleon Effect, (Hattie \& Yates, 2014)).

The lesson design followed the 5E Instructional Model incorporating five phases: engagement, exploration, explanation, elaboration, and evaluation (Sotirou, Bybee, \& Bogner, 2017) concretised in the creativity-based pedagogical framework established within the CREATIONS project (Chappell et al., 2019). A strong emphasis was placed on 
inquiry-based learning with the features of dialogue, risk, immersion and play, and inter-disciplinary framework, the application of which can help make science teaching and the learning process inspiring and engaging for both teachers and students (Alexopoulos et al., 2019). A series of hands-on activities using inexpensive everyday materials suitable for primary school classrooms was applied (Table 1, Pavlidou \& Lazzeroni, 2016).

Providing space for creativity requires a social environment where students imagine, explore, experiment, test, manipulate, take risks, speculate and are allowed to make

Table 1 Examples of the subject areas, questions and type of activities used by teachers (Alexopoulos et al., 2019)

\begin{tabular}{|c|c|c|}
\hline Subject & Questions & Activities \\
\hline CERN & $\begin{array}{l}\text { - What happens at CERN? } \\
\text { - What does the LHC do? } \\
\text { - How do particle detectors work? }\end{array}$ & $\begin{array}{l}\text { - Animated videos with photos } \\
\text { of student's work } \\
\text { - Group work - poster/model } \\
\text { making } \\
\text { - Video link session with CERN } \\
\text { - Web page displaying } \\
\text { student's research work } \\
\text { - Immersion play activities } \\
\text { (games using digital apps) } \\
\text { - Creative story/comic writing }\end{array}$ \\
\hline $\begin{array}{l}\text { The scientific } \\
\text { process }\end{array}$ & $\begin{array}{l}\text { - Why and how did early man discover science? } \\
\text { - How does science work (observations, patterns, possible } \\
\text { explanations, testing experiments, revisions, judgements)? } \\
\text { - How do we know what we know? }\end{array}$ & $\begin{array}{l}\text { - "Black box" activity } \\
\text { - Immersion play } \\
\text { - activities (puzzles) } \\
\text { - Simple class experiments } \\
\text { - Animated videos }\end{array}$ \\
\hline $\begin{array}{l}\text { Famous } \\
\text { scientists }\end{array}$ & $\begin{array}{l}\text { - What did Newton believe about gravity? } \\
\text { - What did Einstein believe about gravity? } \\
\text { - What did the ancient Greeks know about science? } \\
\text { - Who are the most important physicists of the 19th and } \\
\text { twentieth century and what did they discover? }\end{array}$ & $\begin{array}{l}\text { - Group work - poster/model } \\
\text { making } \\
\text { - Immersion play activities } \\
\text { (treasure hunt) }\end{array}$ \\
\hline $\begin{array}{l}\text { Fundamental } \\
\text { particles }\end{array}$ & $\begin{array}{l}\text { - What are the fundamental particles of matter? } \\
\text { - How do particles interact with one another? }\end{array}$ & $\begin{array}{l}\text { - Immersion play Activities } \\
\text { (dramatization, quiz) } \\
\text { - Group work - poster/model } \\
\text { making } \\
\text { - Creative story/comic writing }\end{array}$ \\
\hline $\begin{array}{l}\text { Fundamental } \\
\text { forces }\end{array}$ & $\begin{array}{l}\text { - What is gravity? } \\
\text { - How do fundamental forces compare in strength? }\end{array}$ & $\begin{array}{l}\text { - Immersion play activities } \\
\text { (games) } \\
\text { - Group work - poster/model } \\
\text { making } \\
\text { - Interactive talk with demos } \\
\text { from teacher }\end{array}$ \\
\hline $\begin{array}{l}\text { Structure of } \\
\text { matter }\end{array}$ & $\begin{array}{l}\text { - What are atoms and molecules? } \\
\text { - How did Rutherford discover the structure of the atom? }\end{array}$ & $\begin{array}{l}\text { - Group work - poster/model } \\
\text { making } \\
\text { - Group work using simulations } \\
\text { - Immersion play Activities } \\
\text { (dramatization, cooking) } \\
\text { - Interactive talk with demos } \\
\text { from teacher }\end{array}$ \\
\hline $\begin{array}{l}\text { Matter and } \\
\text { Antimatter }\end{array}$ & $\begin{array}{l}\text { - What is antimatter? } \\
\text { - How does matter interact with antimatter? }\end{array}$ & $\begin{array}{l}\text { - Group work - poster/model } \\
\text { making } \\
\text { - Immersion play activities } \\
\text { (dramatization) }\end{array}$ \\
\hline Light & - How do the different colors of visible light combine? & - Simple class experiments \\
\hline Cosmology & $\begin{array}{l}\text { - How did the Universe begin? } \\
\text { - What is in our solar system? } \\
\text { - Why is the sky at night black? } \\
\text { - What is the relative size of planets, stars, galaxies? }\end{array}$ & $\begin{array}{l}\text { - Creative story writing } \\
\text { - Sky observation using mobile } \\
\text { phone apps } \\
\text { - Group work - poster/model } \\
\text { making } \\
\text { - Creative story/comic writing }\end{array}$ \\
\hline
\end{tabular}


mistakes. In such environments, students can consider ideas or theories from different perspectives and have the opportunity to create innovative ideas based on their own experiences. For this, teachers were encouraged to adopt the role of tutors, advising on cooperative work, interaction and enquiry based learning while maintaining responsibility for the well-structured learning environment provided by the lesson modules (Table 1; Alexopoulos et al., 2019; Pavlidou \& Lazzeroni, 2016). These modules gave students self-responsibility and space to develop their self-efficacy in dealing with problems and scientific questions.

\section{Test design}

Students were monitored with a pre-test (T0) at the beginning of a school year and a post-test (T1) about 8 months later, following the weekly lessons. An extended period in between of scales application prevented memory effects. Students had sufficient experiences with computers to fill in the online questionnaires. The online data collection reduced the workload for teachers and simplified digitization. For privacy protection reasons, the names of the schools and classes involved were not collected. Participants were not aware of the testing cycles. The questionnaire's completion required about 25 min at each testing. Weekly lessons used the educational tools provided with the CrEATIONS Portal. The professional development program ensured with the provided learning instruction and material that all participating classes were similar educated.

\section{Instruments}

All questionnaires as online tests were completed under controlled conditions. The questionnaires were kept brief to avoid overload, using short subscales with a total of 18 items. To measure relevant factors indicating motivation we selected two subscales from the Science Motivation Questionnaire SM (Schumm \& Bogner, 2016): career motivation (CM), and self-efficacy (SE), using a 5-point Likert scale pattern ranging from "never" (1) to "always" (5). Four items were selected from each subscale (Table 2). As an example given for the two subscales, an item of CM is "Understanding science will benefit me in my career", and of SE is "I believe I can master science knowledge and skills". The strong factor structure of the SM toolset allows for this reduction in the number of items (Ferdous \& Plake, 2016; Marth \& Bogner, 2017a).

Table 2 Items of the science motivation questionnaire

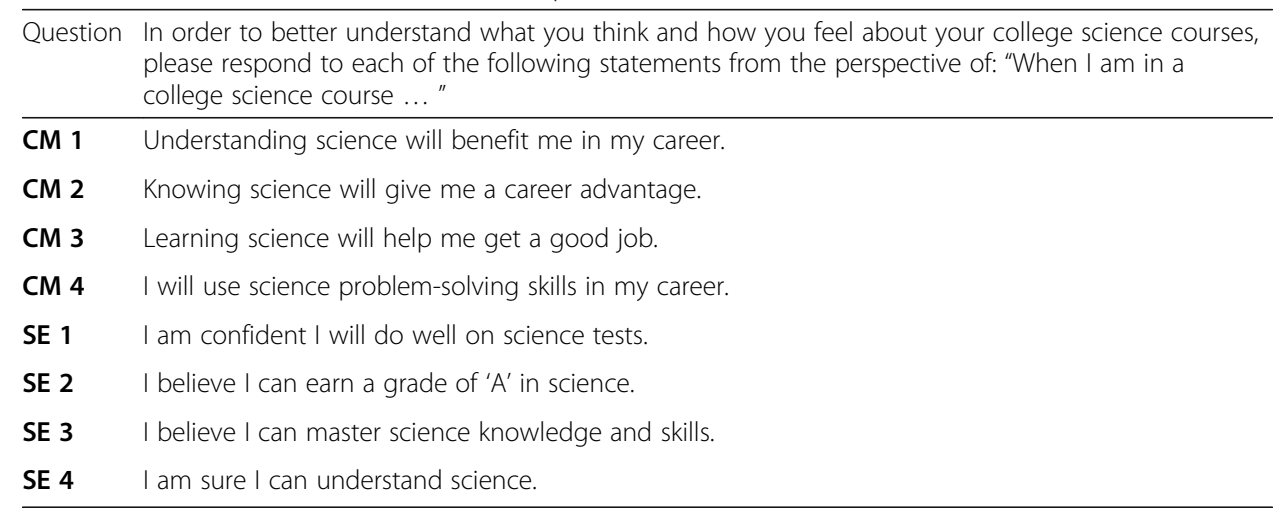


The different definitions of creativity differ primarily in that they evaluate the place, the process or the product. The decisive creativity factor seems to be the person, and psychosocial factors determine the prerequisites for burgeoning creativity. Due to the poor observability of creativity its empirical measurement often faces difficulties (Torrance, 2011). Should the product, the creative process or a person be evaluated? Therefore, we focused on self-reportable traits associated with emotional and "cognitive processes associated with Creativity". The CPAC questionnaire (Miller \& Dumford, 2016) was applied to measure creativity by using two subscales (Table 3):. The first one was labelled АCT, quantifying cognitive processes that are carried out consciously and actively: idea manipulation, imagery, analogical thinking and idea generation. It can be trained and taught. An exemplary item is "I looked at a problem or task from a different angle to find a solution." The second factor with three items was labelled as FLOw, as all items are typical elements of a flow experience (Csikszentmihalyi, 2000). Miller (2014) named this set of items FLOW only in the extended version of the questionnaire. This factor is assumed to measure an essential element of students' motivational experiences at school associated with creativity. An exemplary item is "I lost track of time when intensely working". The creativity measure employed a 4-point Likert scale from ranging from "never" (1) to "very often" (4).

\section{Data analysis procedure}

For statistical analyses, IBM SPSS Statistics 24.0 was used. Following the central limit theorem, we assumed a normal distribution of the data (Wilcox, 2012, p.9). Outliers were rejected. Unfortunately, not all participants completed all both tests, so that the $\mathrm{N}$ was different varies in with the different analyses. Changes across the two test times were analyzed using t-test. Welch-tests were used for the evaluation of gender differences (Ruxton, 2006). The analyses for the canonical correlation were based on complete, matching pre-post-testing sets a sample of $(N=138)$ with complete tests. We calculated the canonical correlation analysis (CCA) measuring the strength of association between the two latent constructs SM and CPAC, each of which is derived from four underlying variables. The structural equation model (SEM) was based on theoretically valid variables and their bivariate correlations. CM T1 was set as a controlled

Table 3 Creativity test CPAC

\begin{tabular}{ll}
\hline Question & During the current school year, about how often have you done each of the following? \\
\hline A1 & Tried to generate as many ideas as possible when approaching a task \\
A3 & Asked other people to help generate potential solutions to a problem \\
A4 & Looked at a problem or task from a different angle to find a solution \\
A5 & Joined together dissimilar concepts to create a novel idea \\
A6 & Incorporated a previously used solution in a new way \\
A7 & Made a connection between a current problem or task and a related situation \\
F1 & Imagined a potential solution to explore its usefulness \\
F2 & Been fully immersed in your work on a problem or task \\
F3 & Lost track of time when intensely working \\
\hline
\end{tabular}

A Act, $F$ Flow 
parameter, and SE T1, ACT, and FLOW were set as covariates to control their effects on the controlled parameter, the measured post-test Career Motivation CM. The goodness of fit of the models was based on a chi-square-test $(p>.05)$ sand the values of the relevant statistics of the goodness of fit: NFI, CFI and RMSEA.

\section{Results}

\section{Effects of STEAM resulting in changes of motivation and creativity}

Effects of the STEAM intervention were examined using the level of changes in the factor level between pre- and post-test. Both creativity subscales (ACT and FLOw) and the motivation subscale Self-Efficacy-scores (SE) increased after the intervention ( $\mathrm{t}$-Tests ACT $\mathrm{t}(137)=-3.762, p<.001$, FLOW $\mathrm{t}(206)=-3.490, p=.001 ;$ SE $\mathrm{t}(137)=-2.386$, $p=.018$; Fig. 2). As the motivational parameters scored on the upper half of the scale, we assumed a satiation effect. Thus, the increase in Self-Efficacy is even more striking.

There is no difference in Career Motivation-scores (CM) before and after the STEA $M$ intervention $(\mathrm{t}(137)=-1.336, p=.184)$, which is an effect of the girls' uneffected motivation, although boys' scores increased. The gender-separated analysis revealed that Career Motivation scores for boys, but not for girls, increased significantly after the STEAM intervention (Fig. 2; Boys CM $\mathrm{t}(64)=-2.52, p=.014$; Girls CM $\mathrm{t}(72)=-$ $0.30, p=.764)$. Nonetheless, gender differences were not significant at any test time at any scale $(N=138$, Levene $p>.1)$.

\section{The interrelation of creativity and motivation}

In order to recognize the mutual relationship between motivation and creativity, we first calculated a canonical correlation. The canonical correlation measures the strength of association between the two latent constructs SM and CPAC (Fig. 3, Tables 4 and 5), each of which is derived from four observed variables. The canonical correlation of 0.647 is highly significant (Wilk's Lambda $=1.087$; d.f. $=16,514 ; p<0.001$ ). The standardized canonical coefficients of the observed variables on the constructs show that SE T0 (loading

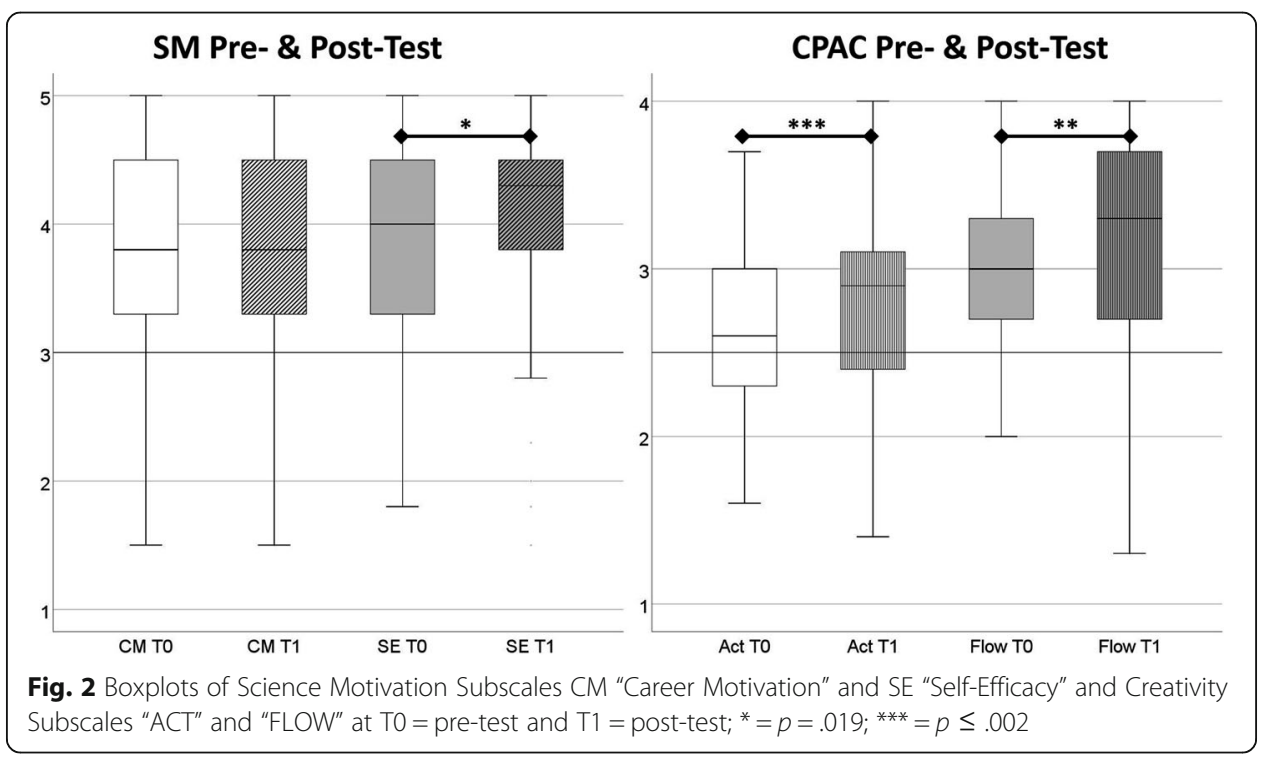




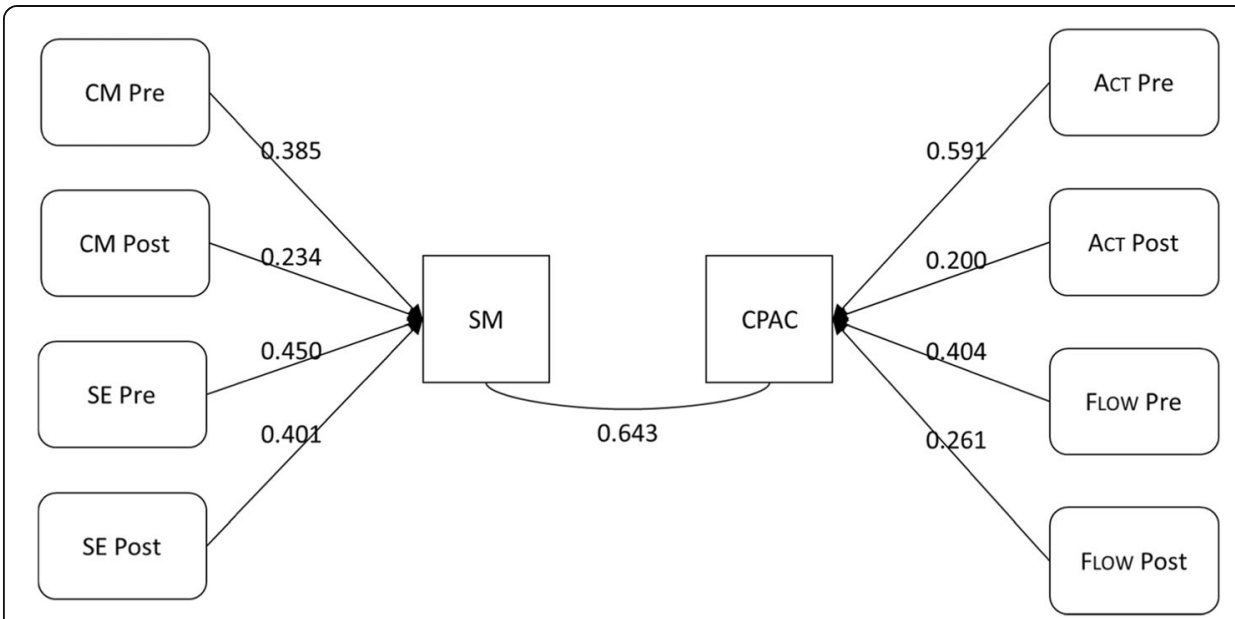

Fig. 3 Canonical Correlation and Standardized Canonical Coefficients (loadings) (SM Subscales: CM = Career Motivation; SE = Self-Efficacy; Creativity Subscales "Act" and "Flow" at Pre-test $=$ T0 and Post-test $=\mathrm{T} 1$ )

0.45) is the largest determinant of SM, though CM T0 and SE T1 also play a role, while CM T1 contributes relatively little. The construct CPAC is dominated by ACT T0 and FLOW T0.

A structural equation model (SEM) pointed to the relation of the variables. Gender was non-significant with any other variable and did not contribute to the model. According to the bivariate correlation, CM T1 was set as a controlled parameter, and SE T1, ACT T1, and FLOW T1 as covariates to control the effect. The final model, containing only significant effects, fit the data well. The chi-squared statistic was insignificant $\left(x^{2}=1.328, \mathrm{df}=1, p=0.249\right)$ and the values of the relevant statistics of the goodness of fit were acceptable $(\mathrm{NFI}=0.993$; $\mathrm{CFI}=0.998$; $\mathrm{RMSEA}=0.024)$. The final path model is presented in Fig. 4 (Table 6).

\section{Discussion}

\section{Effects in creativity and motivation: changes with time?}

In the present study, for the first time, a PD was evaluated by measuring the changes in students' creativity and motivation. The PD had an impact on the way the teachers worked so that in particular the effects on the creativity and motivation of the students were measurable': Self-efficacy, Act and Flow increased.

\section{Gender effects}

Although boys were more inspired for a science career by the intervention than girls were, no significant gender effect appeared. These findings contradict previous studies

Table 4 Correlations between the raw SM variables and their canonical variate

\begin{tabular}{ll}
\hline Science motivation variables & Canonical variate \\
\hline CM T0 & -.70235 \\
CM T1 & -.50926 \\
SE TO & -.75189 \\
SE T1 & -.67111 \\
\hline
\end{tabular}


Table 5 Correlations between the raw creativity variables and their canonical variate

\begin{tabular}{ll}
\hline Creativity variables & Canonical variate \\
\hline Act T0 & -.80300 \\
Act T1 & -.59965 \\
Flow T0 & -.69131 \\
Flow T1 & -.48426 \\
\hline
\end{tabular}

about self-efficacy expectancies in career-related behaviours and career choices of young women (Betz \& Hackett, 1986). The perceptible difference between genders may be overrated in everyday life, and they may actually hardly play a role anymore. Latest studies had pointed to other factors why girls are less likely to pursue careers in physics or engineering (e.g. (Keller, 2001; Martinot \& Désert, 2007; Marx \& Roman, 2016; McKown \& Weinstein, 2003). A reason for this may lie in the young ages of our sample, where children may not have fully taken over the gender roles, whether natural or created through education (e.g. Martin \& Ruble, 2016). A STEAM education seems to offer a pleasant experience for both genders and may also prevent discrimination. Through the self-responsible learning environment with research phases, every student can work in his or her way. Mishkin et al. found that young women were influenced by the subjective norm factor (other people) more than men (Mishkin, Wangrowicz, Dori, \& Dori, 2016). Thus, female science teachers and contact with inspiring female scientists may help girls to keep on their interest in science. In the context of current literature, our results underline the importance of open-minded teachers and learning facilitators so that students develop according to their interests and talents.

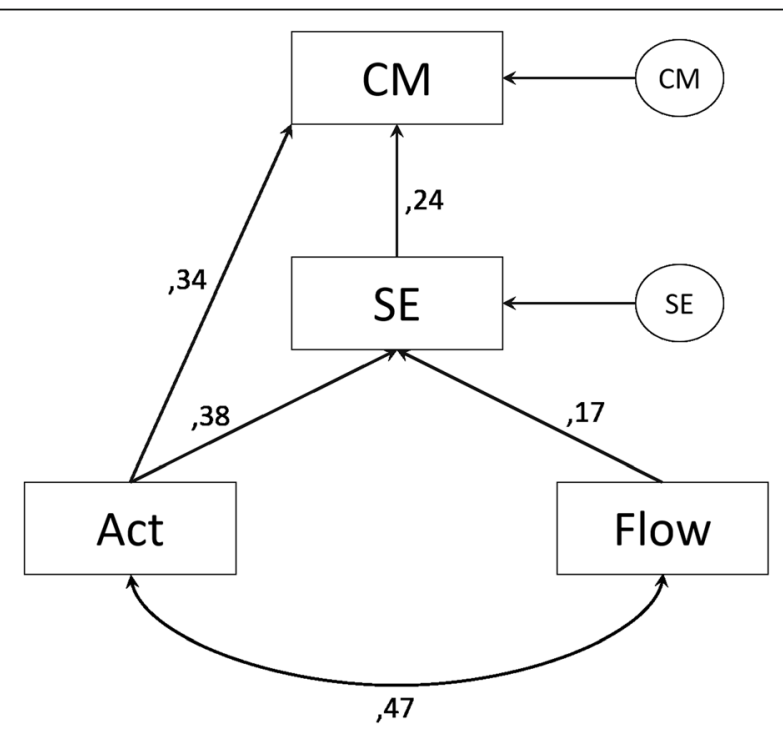

Fig. 4 SEM of Career Motivation through Self-Efficacy and Creativity at measuringtime T1 (Post-test) 
Table 6 Bivariate correlations of the variables (pearson) $N \geq 138$

\begin{tabular}{|c|c|c|c|c|c|c|c|c|c|c|}
\hline & & gender & CM TO & CM T1 & SE TO & SE T1 & Аст T0 & Аст T1 & FLow T0 & FLow $\mathrm{T1}$ \\
\hline \multirow[t]{2}{*}{ gender } & Cor & 1 & &,- 115 & & & & & & \\
\hline & $\mathrm{N}$ & 550 & & 220 & & & & & & \\
\hline \multirow[t]{2}{*}{ CM T0 } & Cor &,- 029 & 1 &, $275^{* * *}$ & & & & & & \\
\hline & $\mathrm{N}$ & 468 & 468 & 138 & & & & & & \\
\hline \multirow[t]{2}{*}{ CM T1 } & Cor &,- 115 &, $275^{* * *}$ & 1 & ,083 &, $387^{* * *}$ &, $172^{*}$ &, $438^{* * *}$ & ,093 &, $300^{* * *}$ \\
\hline & $\mathrm{N}$ & 220 & 138 & 220 & 138 & 220 & 138 & 220 & 205 & 220 \\
\hline \multirow[t]{2}{*}{ SE TO } & Cor & ,019 &, $489^{* * *}$ & ,083 & 1 & & & & & \\
\hline & $\mathrm{N}$ & 468 & 468 & 138 & 468 & & & & & \\
\hline \multirow[t]{2}{*}{ SE T1 } & Cor & ,049 & ,155 &, $387^{* * *}$ & $298^{* * *}$ & 1 & & & & \\
\hline & $\mathrm{N}$ & 220 & 138 & 220 & 138 & 220 & & & & \\
\hline \multirow[t]{2}{*}{ Аст ТO } & Cor &,- 030 &, $475^{* * *}$ &, $172^{*}$ &, $491^{* * *}$ &, $233^{* *}$ & 1 & & & \\
\hline & $\mathrm{N}$ & 468 & 468 & 138 & 468 & 138 & 468 & & & \\
\hline \multirow[t]{2}{*}{ Аст $\mathrm{T1}$} & Cor & , 104 & ,110 &, $438^{* * *}$ & ,151 &, $455^{* * *}$ &, $309^{* * *}$ & 1 & & \\
\hline & $\mathrm{N}$ & 220 & 138 & 220 & 138 & 220 & 138 & 220 & & \\
\hline \multirow[t]{2}{*}{ FLow T0 } & Cor &, 074 & $298^{* * *}$ & ,093 &, $328^{* * *}$ & ,033 &, $352^{* * *}$ &, $139^{*}$ & 1 & \\
\hline & $\mathrm{N}$ & 535 & 468 & 205 & 468 & 205 & 468 & 205 & 535 & \\
\hline \multirow[t]{2}{*}{ FLow T1 } & Cor & ,093 & ,049 &, $300^{* * *}$ & , 156 &, $351^{* * * *}$ & ,088 &, $471^{* * * *}$ & ,079 & 1 \\
\hline & $\mathrm{N}$ & 220 & 138 & 220 & 138 & 220 & 138 & 220 & 205 & 220 \\
\hline
\end{tabular}

How are creativity and motivation related to each other?

Canonical correlation

According to the Canonical Correlation, the most significant determinant of Science Motivation (SM) was self-efficacy. Although Career Motivation before the intervention (CM T0) and Self-Efficacy after the intervention (SE T1) are still important, Career Motivation after the intervention (CM T1) does not contribute to Science Motivation (SM). This underlines the importance of Self-Efficacy as the most reliable predictor for Science Motivation. (Young) people need the opportunity to experience their skills and to perceive themselves as capable of coping with unknown situations and problems in order to master life appropriately in stress resistance and fearlessness (Bandura, 2012). With mastered experience, anxiety levels may decrease with increasing self-efficacy (Lent, Lopez, Brown, \& Gore, 1996). What applies, in general, can also be applied to science teaching: successful STEM offers a learning environment in which the student can stress-free discover his/her scientific skills, ideally as an aside. Children's self-efficacy and self-confidence must be encouraged in order to maintain students' motivation and willingness to perform. Knowledge transfer should not be the focus; it is the result of education, which encourages self-confidence.

Although this STEAM intervention may not have fostered very young students' interest in a science career, it may support students' general motivation. Similar results are found for Creativity, where the strongest determinants for CPAC are ACT and FLOW before the intervention (ACT T0, FLOW T0). Thus, students' already developed components had determined both Motivation and Creativity, but not attitudes that students developed with our STEAM education. Although we could provide evidence that 
regular STEAM education fosters students' ability in creative thinking processes, their self-efficacy in earlier experiences seem to have a more profound influence on students' motivation and creativity. On the one hand, this could be explained by the fact that 1 hour weekly lesson in Grade 4 does not yet turn schools into an environment that encourages creativity and motivation. It is one experience among many that shape students' expectations and behaviour.

Nevertheless, our results still show an impact of just a weekly hour lesson. It, therefore, appears to be a promising and sustainable approach in children's education to promote autonomy and creativity as early as part of the routine and not as a rare intervention. Thus, education has to promote children's autonomy and creativity much earlier, more impressively and regularly, not on rare occasions.

STEAM is clearly on the right track for modern education, but it must not remain an exotic individual measure. The principles of creativity need integration in any subject and everyday education (Brodbeck, 1999). Just as a painting is a product, but the artist has focused on the creative process, imparting cognitive knowledge must be regarded as an end product of a lesson, not as the center of attention. A student-centered process of knowledge exploration should be the focus. Especially in the natural sciences, the chances for self-reliant learning through experimentation and trial and error experience are obvious. At the end of the lesson, the students captured the subject matter and acquired competences with the motivating experience of having achieved this independently with self-responsibility (Popp, 2016). Students may not gain full scores in knowledge tests after a self-regulated lesson, but the knowledge they gained on their own is sustained (Conradty \& Bogner, 2011) and thus requires no repetition in later school years. Self-regulated learning may initially be more time-consuming, but in the long-term, it saves the need for repetitions, thanks to the stability of the knowledge acquired.

\section{Structural equation model}

In the present study, a substantial increase in cognitive creativity components and motivation, especially in self-efficacy, appeared. The canonical correlation showed motivation and creativity as determinants of our pre-study values. Additionally, bivariate correlations indicated the Self-Efficacy path to be linked to the path of Career Motivation. Thus, the SEM indicated that career motivation (CM T1) after the intervention was effected strongly by the self-efficacy (SE T1). Both CM and SE were determined by ACT, the active cognitive aspects of creativity. FLOW has an influence on SE, albeit less than ACT. These results are in line with expectation, as self-efficacy has proved to provide insights into undergraduate 'students' career development in STEM fields (Pajares, 2016). The present study confirmed the self-efficacy model that was set up by Conradty and Bogner (2020a, b) using the data from 5 STEAM modules of the CREA TIONS project. Creativity factors determined SE and through this path CM. Since selfefficacy has a substantial impact on self-responsibility and activity (Bandura, 2012), this may be a strong argument in favour of more active creativity in the classroom.

We emphasize that we distinguish between active and passive creativity. The latter is when students passively enjoy creativity in arts or teachers' creativity in his/her lessons. Active creativity requires students to solve tasks independently. According to Guilford 
(1950), creativity is just a form of thinking. Taking into account the creativity factor "productivity", action must follow the idea in order to turn the creative idea into more than just an idea.

Our findings are in line with the literature: the close connection between self-efficacy and creativity is evident when we examine the factors supporting them (Chappell et al., 2019; Conradty \& Bogner, 2020b; Hetherington et al., 2020). Self-efficacy is the belief in one's capabilities to organize and execute the sources of action required to manage prospective situations (Bandura, 2012). Self-efficacy is a key to competent self-regulation by influencing thinking, feeling and acting. It strengthens motivation and willpower and promotes ambitious goals, effort, stamina and performance. Self-efficacy is perceived as the representation of the personal perception of external social factors (Bandura, 2012). It is strongly affected by the feedback of the social environment and can thus be supported or weakened.

A critical factor that can be both supporter and blocker of self-efficacy and creativity is the teacher and his classroom. A teacher-centred lesson focussing on effectiveness may make teachers help learners more than essential. A highly controlled learning deprives the student of the chance to master the classroom challenge and to enjoy the experience of self-efficacy. Learning occurs more passively than it is actively worked on, which might lead to decreasing motivation and a desire to learn (Heyne \& Bogner, 2010; Heyne \& Franz, 2013; Marth \& Bogner, 2017b; Schmid \& Bogner, 2017). A work environment focusing on results and testable knowledge may stifle creativity, and in highly organized closed learning environments often a part of the class is less stimulated or encouraged, for example, because of the type of learner or the gender. Impulses from social backgrounds, working climates and education experiences lead to behaviours that promote or inhibit creative potential. How the teacher and classmates deal with errors and mistakes is crucial to the success or failure of self-directed and inquirybased learning (Conradty \& Bogner, 2016). When a perfect lesson is a stated goal, this may cause strict target orientation, and problem-solving rituals are used inadequately. Instead of having fun with try and error learning (Thagard \& Stewart, 2011), an inquiry-based creative learning settings without an adequate mindset of the teacher may cause fear, disappointment, failure and mistakes in both students and teachers (Grant, Grant, \& Gallate, 2012). A helpful error management culture with no blame for failures may help to avoid such developments, develop positive self-efficacy and promote the relationship. For social distance inhibits creativity (Sosa, 2011), indicating the importance of relationships with both classmates and the teacher. Another cultural disadvantage for creativity is the concept of separation of work and play: Playful testing can encourage the development of something new (Csikszentmihalyi, 2000). Kim \& Park point to the importance of play (Kim \& Park, 2012). (Science) learning should be more like Rube Goldberg machines: with such artworks, children learn about mechanics with the pleasure in observing and a playful spirit of research about feasibility - and without any need for seriousness and usefulness.

\section{Conclusion}

The reported PD design is a promising blueprint for modern dissemination, especially to infuse new innovative methods into classrooms. When PDs use the same teaching strategies as teachers are expected to implement and use later, a first foot is in the 
door. When appropriate teaching materials are provided to enable teachers a more extended period of usage, the door is open. Our presented STEAM lesson instruction showed its successful influence on students' creativity and self-efficacy. Although we just assessed the PDs indirectly via students effects a motivating atmosphere with a reflection on success with particular attention to overcoming obstacles and learning by example revealed effective and following other blueprints (Pajares, 2016; Spencer, Lucas, \& Claxton, 2012). Probably the most crucial factor in the design of the present study was that all participating teachers had learned a new subject in the same playful way as they were expected to teach their students later. This design was elementary for the study, as a competition of conventional teaching concepts with the new STEAM concepts was prevented. A new way of educating was founded as teachers had no previous experience, and they could not relapse in old-fashioned ways of teaching.

The fact that CM was not affected is not surprising as because of their youth, participants had probably not yet developed career maturity and concerning motivation (Lau, Chung, \& Wang, 2019). SE and creativity were affected by our creative STEAM instruction. This result shows that a one-time PD can be effective if it is integrated into the subsequent daily teaching routine. In the present study, this aim was challenging to achieve, since the focus was not on cognitive knowledge, but to what extent the changed teaching strengthened emotional and motivational factors of students. It should be emphasized that interest and self-confidence are regarded as essential triggers to reach deeper levels of knowledge. Students with low self-esteem particularly benefit of inquiry-based methods as applied in our module (Rocard et al., 2007). As self-efficacy is considered to be associated with responsibility (Lau, Kitsantas, Miller, \& Drogin Rodgers, 2018) and Flow with happiness perception (Csikszentmihalyi, 2000), STEAM may offer a promising approach to promote both school motivation and willingness to perform. Creativity in education promises to develop a school that meets the modern notions of learning and success (National Research Council [NRC], 2012).

Creativity and science are closely related to providing a new understanding of the natural world (Meyer \& Lederman, 2013). This understanding follows the early definition of creativity as the ability to come up with new useful ideas (Mumford, 2003) or solve a problem in a new practical and unprecedented way (Guilford, 1950). Thus, it is obvious how creativity can promote science education. This outlines a guideline for integrating creativity in education. Students need the scope to deal with the topic being taught (Sturm \& Bogner, 2008).

The teacher needs to accept two new role models: on the one hand his/her role as a mentor (Conradty \& Bogner, 2016) with the task of providing an appropriate learning environment with suitable learning material (Novak \& Cañas, 2006). The tutor's task is not to impart knowledge, but to prepare an learning conductive environment with a curiosity-promoting research question and a pre-selection of the work material, adapted to the students' performance. On the other hand, the student as a mature learner who carries out the tasks with self-responsibility (Conradty \& Bogner, 2020a). The first might exemplify faith in the students and openness to students through their behaviour. The second offers students the experience of self-efficacy and self-determination of the learning processes - and the spirit of research. 


\title{
Limitation
}

Our focus on career motivation, a subscale of science motivation, did not reach young students (Conradty \& Bogner, 2020b). Below the age of fourteen, apparently, career orientation is not yet an issue as our students were woundering how to respond. To sustain the STEAM PD efforts, two control groups would have been impressive: The first one should have followed a conventional instruction without STEAM, the second one performing the STEAM PD without the weekly work materials. Thus, this group would have not enjoyed the weekly repetition. Finding control classes that only fill out questionnaires without experiencing the benefits of the study is very difficult. It is questionable to offer teachers an incomplete PD without the material. Furthermore, this was an incomparable treatment situation. That is why this sophisticated design was not feasible.

\begin{abstract}
Abbreviations
STEM teaching: ScienceTechnologyEngineering and Mathematics; STEAM: STEM integrating arts (A) and creativity; PD: Professional Development; CCA: Canonical Correlation Analysis; SEM: Structural Equation Model; SM: Science Motivation Questionnaire; CM: Science Motivation Subscale Career Motivation; SE: Science Motivation Subscale SelfEfficacy; CPAC: Cognitive Processes associated with Creativity Questionnaire; Act: CPAC subscale Active Processes; FLow: CPAC subscale Flow; T0: Pre-Test before intervention; T1: Post-Test after intervention
\end{abstract}

\section{Acknowledgements}

We would like to thank the Creations consortium team, for instance, A. Alexopoulos, who applied the module at CERN as well as all students and teachers who supported our study, and M. Wiseman for his valuable feedback and statistic advice.

\section{Authors' contributions}

Conceptualization, CC and FXB; methodology, CC; formal analysis, CC; writing-original draft preparation, CC; writing - review and editing, CC and FXB; supervision, FXB; project administration, FXB; funding acquisition, FXB. The author(s) read and approved the final manuscript.

\section{Authors' information}

Dr Cathérine Conradty (with a PhD in Science Education) works as post-doc at the Department of Biology Education and the Centre of Math \& Science Education (Z-MNU) of the University of Bayreuth. Her research field, in general, is for$\mathrm{mal}$ and informal science education at the primary and secondary level, by analysing traditional variables such as cognitive learning or motivation. Her focus is on specific impellent factors on motivation such as maturity, ideas of adolescence, or, in the case of the present study, creativity.

Prof. Franz X. Bogner (with a PhD in Neurobiology, a post-doctoral fellowship at the Cornell University, USA, as well as a habilitation in Biology Education) is a full professor and head of the Department of Biology Education as well as the director of the Z-MNU (Centre of Math \& Science Education) at the University of Bayreuth. His research mainly focusses on assessment of science / environmental education, in pre-service teacher education and in-service teacher enhancement. Prof. Bogner's research projects consistently include cognitive (and emotional and attitudinal) assessment.

\section{Funding}

This work was supported by the European HORIZON-2020 framework labelled CREATIONS: Developing an Engaging Science Classroom (Grant Agreement No.665917; http://creations-project.eu), submitted by FXB. The APC was funded by the German Research Foundation (DFG) and the University of Bayreuth in the funding program Open Access Publishing under grant agreement no. LA 2159/8-6. The funders had no role in the design of the study, in the collection, analyses, or interpretation of data, in the writing of the manuscript, or in the decision to publish the results. This article reflects only the authors' views. The European Commission and the DFG are not liable for any use that might be made of the information contained herein.

\section{Availability of data and materials}

The datasets generated and analysed during the current study are available in the ZENODO repository, https://doi.org/ $10.5281 /$ zenodo. 3243214

\section{Competing interests}

The authors declare that they have no competing interests.

Received: 31 May 2020 Accepted: 24 August 2020

Published online: 06 October 2020

\section{References}

Alexopoulos, A., Pavlidou, M., \& Cherouvis, S. (2019). 'Playing with protons': a training course for primary school teachers at

CERN. Physics Education, 54(1), 15013. https://doi.org/10.1088/1361-6552/aae7a4 . 
Archer, L., DeWitt, J., Osborne, J., Dillon, J., Willis, B., \& Wong, B. (2013). 'Not girly, not sexy, not glamorous': Primary school girls' and parents' constructions of science aspirations 1. Pedagogy, Culture and Society, 21(1), 171-194. https://doi.org/10. 1080/14681366.2012.748676

Bandura, A. (2012). Self-efficacy: the exercise of control (13. Printing). New York: Freeman.

Barbot, B., Besançon, M., \& Lubart, T. (2015). Creative potential in educational settings: its nature, measure, and nurture. Education 3-13, 43(4), 371-381. https://doi.org/10.1080/03004279.2015.1020643.

Bennett, J., \& Hogarth, S. (2009). Would you want to talk to a scientist at a party? High school students' attitudes to school science and to science. International Journal of Science Education, 31(14), 1975-1998. https://doi.org/10.1080/ 09500690802425581

Betz, N. E., \& Hackett, G. (1986). Applications of self-efficacy theory to understanding career choice behavior. Journal of Social and Clinical Psychology, 4(3), 279-289. https://doi.org/10.1521/jscp.1986.4.3.279 .

Brodbeck, K.-H. (1999). Entscheidung zur Kreativität, (2nd ed., ). Darmstadt: Wissenschaftliche Buchgesellschaft.

Buczynski, S., \& Hansen, C. B. (2010). Impact of professional development on teacher practice: Uncovering connections. Teaching and Teacher Education, 26(3), 599-607. https://doi.org/10.1016/.jtate.2009.09.006

Chappell, K., Hetherington, L., Keene, H. R., Wren, H., Alexopoulos, A., Ben-Horin, O., ... Bogner, F. X. (2019). Dialogue and materiality/embodiment in science|arts creative pedagogy: Their role and manifestation. Thinking Skills and Creativity, 31, 296-322. https://doi.org/10.1016/.tsc.2018.12.008 .

Conradty, C., \& Bogner, F. (2011). Computer-aided learning: unguided versus guided instruction. Advanced Science Letters, 4(11), 3310-3316. https://doi.org/10.1166/asl.2011.2040 .

Conradty, C., \& Bogner, F. (2016). Hypertext or textbook: effects on motivation and gain in knowledge. Education Sciences, 6(3), 29. https://doi.org/10.3390/educsci6030029.

Conradty, C., \& Bogner, F. X. (2019). From STEM to STEAM:: cracking the code? How creativity \& motivation interacts with inquiry-based learning. Creativity Research Journal, 31(3), 284-295. https://doi.org/10.1080/10400419.2019.1641678 .

Conradty, C., \& Bogner, F. X. (2020a). Conceptual change when growing up: Frameset for role models? International Journal of Adolescence and Youth, 25(1), 292-304. https://doi.org/10.1080/02673843.2019.1622581.

Conradty, C., \& Bogner, F. X. (2020b). How creativity in STEAM modules intervenes with self-efficacy and motivation. Education Sciences, 10(4), 70.

Corazza, G. E. (2016). Potential originality and effectiveness: the dynamic definition of creativity. Creativity Research Journal, 28(3), 258-267. https://doi.org/10.1080/10400419.2016.1195627.

Csikszentmihalyi, M. (2000). Beyond boredom and anxiety, (25th ed., ). San Francisco: Jossey-Bass Publishers.

Csikszentmihalyi, M. (2010). Creativity: flow and the psychology of discovery and invention. New York: Harper.

de Bono, E. (1990). Lateral thinking: creativity step by step (1. Perennial librany ed.). New York: Harper Perennial.

Deci, E. L., Schwartz, A. J., Sheinman, L., \& Ryan, R. M. (1981). An instrument to assess adults' orientations toward control versus autonomy with children: reflections on intrinsic motivation and perceived competence. Journal of Education \& Psychology, 73(5), 642-650. https://doi.org/10.1037/0022-0663.73.5.642 .

Desimone, L. M. (2009). Improving impact studies of teachers' professional development: toward better conceptualizations and measures. Educational Research, 38(3), 181-199. https://doi.org/10.3102/0013189X08331140 .

Epstein, N., \& Fischer, M. R. (2017). Academic career intentions in the life sciences: can research self-efficacy beliefs explain low numbers of aspiring physician and female scientists? PLoS One, 12(9), e0184543. https://doi.org/10.1371/journal.pone. 0184543.

Ermeling, B. A. (2010). Tracing the effects of teacher inquiry on classroom practice. Teaching and Teacher Education, 26(3), 377-388. https://doi.org/10.1016/j.tate.2009.02.019 .

Ferdous, A. A., \& Plake, B. S. (2016). Item selection strategy for reducing the number of items rated in an Angoff standard setting study. Educational and Psychological Measurement, 67(2), 193-206. https://doi.org/10.1177/0013164406288160 .

Ferla, J., Valcke, M., \& Cai, Y. (2009). Academic self-efficacy and academic self-concept: reconsidering structural relationships. Learning and Individual Differences, 19(4), 499-505. https://doi.org/10.1016/j.lindif.2009.05.004 .

Franklin, B., Xiang, L., Collett, J., Rhoads, M., \& Osborn, J. (2015). Open inquiry-based learning elicits deeper understanding of complex physiological concepts compared to traditional lecture-style or guided-inquiry learning methods. The FASEB Journal, 29, 541.22. https://doi.org/10.1096/fasebj.29.1_supplement.541.22.

Grant, A., Grant, G., \& Gallate, J. (2012). Who killed creativity? -- and how we can get it back? Seven essential strategies to make yourself, your team and your organisation more innovative. Milton: Jossey-Bass Retrieved from http://site.ebrary.com/lib/ alltitles/docDetail.action?docID=10538669.

Guilford, J. P. (1950). Creativity. The American Psychologist, 5(9), 444-454.

Guskey, T. R. (2003). Evaluating professional development ([Nachdr.]). Thousand Oaks: Corwin Press.

Guskey, T. R., \& Sparks, D. (2004). Linking professional development to improvements in student learning. In E. Guyton (Ed.), Teacher education yearbook: Vol. 12. Research linking teacher preparation and student performance. Westmark Drive Dubuque (lowa): Kendall/Hunt Publishing Company.

Hattie, J. (2010). Visible learning: a synthesis of over 800 meta-analyses relating to achievement; [reveals teaching's Holy Grail. The Times Educational Supplement] (Repr). London: Routledge.

Hattie, J., \& Yates, G. C. R. (2014). Visible learning and the science of how we learn (1. publ). London: Routledge.

Henriksen, D. (2014). Full STEAM ahead: creativity in excellent STEM teaching practices. STEAM, 1(2), 1-9. https://doi.org/10. 5642/steam.20140102.15.

Hensley, N. (2018). Transforming higher education through trickster-style teaching. Journal of Cleaner Production, 194, 607612. https://doi.org/10.1016/j.jclepro.2018.05.116.

Hetherington, L., Chappell, K., Ruck Keene, H., Wren, H., Cukurova, M., Hathaway, C., ... Bogner, F. (2020). International educators' perspectives on the purpose of science education and the relationship between school science and creativity. Research in Science and Technological Education, 38(1), 19-41. https://doi.org/10.1080/02635143.2019.1575803 .

Heyne, T., \& Bogner, F. X. (2010). Strengthening resistance self-efficacy: influence of teaching approaches and gender on different consumption groups. Journal of Drug Education, 39(4), 439-457. https://doi.org/10.2190/DE.39.4.f .

Heyne, T., \& Franz, X. B. (2013). Drug prevention by increasing self-esteem: influence of teaching approaches and gender on different consumption groups. World Journal of Education, 3(1), 1-12. https://doi.org/10.5430/wje.v3n1p1 . 
Holm-Hadulla, R. M. (2010). Creativity: concept and lifestyle, (3rd ed., ). Göttingen: Vandenhoeck \& Ruprecht.

Keller, C. (2001). Effect of teachers' stereotyping on students' stereotyping of mathematics as a male domain. The Journal of Social Psychology, 141(2), 165-173. https://doi.org/10.1080/00224540109600544 .

Kim, Y., \& Park, N. (2012). The effect of STEAM education on elementary school student's creativity improvement. In T.-H. Kim, A. Stoica, W.-C. Fang, T. Vasilakos, J. Garcia Villalba, K. P. Arnett, et al. (Eds.), Computer applications for security, control and system engineering, (vol. 339). Berlin: Springer. https://doi.org/10.1007/978-3-642-35264-5_16.

Lau, C., Kitsantas, A., Miller, A. D., \& Drogin Rodgers, E. B. (2018). Perceived responsibility for learning, self-efficacy, and sources of self-efficacy in mathematics: a study of international baccalaureate primary years programme students. Social Psychology of Education, 21(3), 603-620. https://doi.org/10.1007/s11218-018-9431-4

Lau, P. L., Chung, Y. B., \& Wang, L. (2019). Effects of a career exploration intervention on students' career maturity and selfconcept. Journal of Career Development, 8, 089484531985338. https://doi.org/10.1177/0894845319853385.

Lent, Lopez, Brown, \& Gore (1996). Latent structure of the sources of mathematics self-efficacy. Journal of Vocational Behavior, 49(3), 292-308. https://doi.org/10.1006/jvbe.1996.0045 .

Marth, M., \& Bogner, F. X. (2017a). How a hands-on BIONICS lesson may intervene with science motivation and technology interest.

Marth, M., \& Bogner, F. X. (2017b). How a hands-on BIONICS lesson may intervene with science motivation and technology interest. International Journal of Learning, Teaching and Educational Research, 16(5), 72-89 https://www.ijlter.org/index. php/ijter/article/view/930.

Martin, C. L., \& Ruble, D. (2016). Children's search for gender cues. Current Directions in Psychological Science, 13(2), 67-70. https://doi.org/10.1111/j.0963-7214.2004.00276.x.

Martinot, D., \& Désert, M. (2007). Awareness of a gender stereotype, personal beliefs and self-perceptions regarding math ability: when boys do not surpass girls. Social Psychology of Education, 10(4), 455-471. https://doi.org/10.1007/s11218-0079028-9.

Marx, D. M., \& Roman, J. S. (2016). Female role models: protecting women's math test performance. Personality and Social Psychology Bulletin, 28(9), 1183-1193. https://doi.org/10.1177/01461672022812004 .

Matud, M. P., Rodríguez, C., \& Grande, J. (2007). Gender differences in creative thinking. Personality and Individual Differences, 43(5), 1137-1147. https://doi.org/10.1016/j.paid.2007.03.006 .

McKown, C., \& Weinstein, R. S. (2003). The development and consequences of stereotype consciousness in middle childhood. Child Development, 74(2), 498-515. https://doi.org/10.1111/1467-8624.7402012.

Meyer, A. A., \& Lederman, N. G. (2013). Inventing creativity: an exploration of the pedagogy of ingenuity in science classrooms. School Science and Mathematics, 113(8), 400-409. https://doi.org/10.1111/ssm.12039.

Miller, A. L. (2014). A self-report measure of cognitive processes associated with creativity. Creativity Research Journal, 26(2), 203-218. https://doi.org/10.1080/10400419.2014.901088 .

Miller, A. L., \& Dumford, A. D. (2016). Creative cognitive processes in higher education. Journal of Creative Behaviour, 50(4), 282-293. https://doi.org/10.1002/jocb.77

Mishkin, H., Wangrowicz, N., Dori, D., \& Dori, Y. J. (2016). Career choice of undergraduate engineering students. Procedia Social and Behavioral Sciences, 228, 222-228. https://doi.org/10.1016/.jsbspro.2016.07.033

Mumford, M. D. (2003). Where have we been, where are we going? Taking stock in creativity research. Creativity Research Journal, 15(2-3), 107-120. https://doi.org/10.1080/10400419.2003.9651403.

National Research Council (NRC) (2012). A framework for K-12 science education:: practices, crosscutting concepts, and core ideas. Washington, DC: The National Academies Press.

Novak, J. D., \& Cañas, A. J. (2006). The theory underlying concept maps and how to construct and use them: technical report IHMC CmapTools. In Institute for human and machine cognition.

Özcan, Z. Ç., \& Eren Gümüş, A. (2019). A modeling study to explain mathematical problem-solving performance through metacognition, self-efficacy, motivation, and anxiety. Australian Journal of Education, 63(1), 116-134. https://doi.org/10. $1177 / 0004944119840073$

Pajares, F. (2016). Self-efficacy beliefs in academic settings. Review of Educational Research, 66(4), 543-578. https://doi.org/10. $3102 / 00346543066004543$

Pavlidou, M., \& Lazzeroni, C. (2016). Particle physics for primary schools-enthusing future physicists. Physics Education, 51(5), 54003. https://doi.org/10.1088/0031-9120/51/5/054003

Pitsia, V., Biggart, A., \& Karakolidis, A. (2017). The role of students' self-beliefs, motivation and attitudes in predicting mathematics achievement: a multilevel analysis of the programme for international student assessment data. Learning and Individual Differences, 55, 163-173. https://doi.org/10.1016/j.lindif.2017.03.014 .

Popp, S. (2016). Der Daltonplan in Theorie und Praxis: Ein aktuelles reformpädagogisches Modell zur Förderung selbstständigen Lernens in der Sekundarstufe (1. Aufl.). s.l.: Studienverlag. Retrieved from http://gbv.eblib.com/patron/FullRecord.aspx?p= 4347391.

Reddy, J. K., Menon, R. K., \& Thattil, A. (2018). Academic stress and its sources among university students. Biomedical and Pharmacology Journal, 11(1), 531-537. https://doi.org/10.13005/bpj/1404 .

Reddy, S., Brothers, K., Quave, C. L., \& Chen, S. C. (2019). Altering perceptions of scientists among fifth graders by the introduction of female role models: a new opportunity for dermatologists? The Journal of Investigative Dermatology, 139(3), 723-724. https://doi.org/10.1016/j.jid.2018.09.017

Rocard, M., Csermely, Peter, Jorde, Doris, Lenz, D., Walber-Henriksson, H., \& Hemmo, V. (2007). Science education now: a renewed pedagogy for the future of Europe. Luxembourg.

Runco, M. A., Acar, S., \& Cayirdag, N. (2017). A closer look at the creativity gap and why students are less creative at school than outside of school. Thinking Skills and Creativity, 24, 242-249. https://doi.org/10.1016/j.tsc.2017.04.003 .

Ruxton, G. D. (2006). The unequal variance t-test is an underused alternative to Student's t-test and the Mann-Whitney U test. Behavioral Ecology, 17(4), 688-690. https://doi.org/10.1093/beheco/ark016 .

Sadeh, I., \& Zion, M. (2009). The development of dynamic inquiry performances within an open inquiry setting: a comparison to guided inquiry setting. Journal of Research in Science Teaching, 46(10), 1137-1160. https://doi.org/10.1002/tea.20310 .

Schmid, S., \& Bogner, F. X. (2015). Effects of students' effort scores in a structured inquiry unit on long-term recall abilities of content knowledge. Education Research International, 2015(2), 1-11. https://doi.org/10.1155/2015/826734 . 
Schmid, S., \& Bogner, F. X. (2017). How an inquiry-based classroom lesson intervenes in science efficacy, career-orientation and self-determination. International Journal of Science Education, 39(17), 2342-2360. https://doi.org/10.1080/09500693. 2017.1380332 .

Schumm, M. F., \& Bogner, F. X. (2016). Measuring adolescent science motivation. International Journal of Science Education 38(3), 434-449. https://doi.org/10.1080/09500693.2016.1147659

Shen, W., Liu, C., Shi, C., \& Yuan, Y. (2015). Gender differences in creative thinking. Advances in Psychological Science, 23(8), 1380. https://doi.org/10.3724/SP.J.1042.2015.01380

Sosa, D. (2011). Some of the structure of experience and belief. Philosophical Issues, 21(1), 474-484. https://doi.org/10.1111/j. 1533-6077.2011.00212.x

Sotirou, S., Bybee, R. W., \& Bogner, F. X. (2017). PATHWAYS - a case of large-scale implementation of evidence-based practice in scientific inquiry-based science education. International Journal of Higher Education, 6(2), 8. https://doi.org/10.5430/ijhe. v6n2p8 .

Spencer, E., Lucas, B., \& Claxton, G. (2012). Progression in creativity: developing new forms of assessment:: final research report. Newcastle: CCE: Center of Real World Learning.

Sturm, H., \& Bogner, F. X. (2008). Student-oriented versus teacher-centred: the effect of learning at workstations about birds and bird flight on cognitive achievement and motivation. International Journal of Science Education, 30(7), 941-959. https://doi.org/10.1080/09500690701313995.

Supovitz, J. A., \& Turner, H. M. (2000). The effects of professional development on science teaching practices and classroom culture. Journal of Research in Science Teaching, 37(9), 963-980. https://doi.org/10.1002/1098-2736(200011)37:9<963::AIDTEA6 $>3.0 . C O ; 2-0$

Thagard, P., \& Stewart, T. C. (2011). The AHA! Experience: creativity through emergent binding in neural networks. Cognitive Science, 35(1), 1-33. https://doi.org/10.1111/j.1551-6709.2010.01142.x.

Tooke, D. J., \& Lindstrom, L. C. (1998). Effectiveness of a mathematics methods course in reducing math anxiety of preservice elementary teachers. School Science and Mathematics, 98(3), 136-139. https://doi.org/10.1111/j.1949-8594.1998.tb17406.x .

Torrance, E. P. (2011). The nature of creativity as manifest in its testing. In R. J. Sternberg (Ed.), The nature of creativity: contemporary psychological perspectives, (pp. 43-75). Cambridge: Cambridge University Press.

Urban, K. K. (1991). On the development of creativity in children. Creativity Research Journal, 4(2), 177-191. https://doi.org/10. 1080/10400419109534384

Van Veen, K., Zwart, R., \& Meirink, J. (2012). Teacher learning that matters:: international perspectives. In M. Kooy, \& K. van Veen (Eds.), Routledge research in education: Vol. 62. Teacher learning that matters: international perspectives, (pp. 3-21). New York: Routledge.

Wagner, T. (2010). The global achievement gap: why even our best schools dont teach the new survival skills our children need and what we can do about it. New York: Basic Books Retrieved from http://www.socialnet.de/rezensionen/isbn.php?isbn= 978-0-465-00229-0.

Wilcox, R. R. (2012). Introduction to robust estimation and hypothesis testing. In Statistical modeling and decision science, (3rd ed., ). Amsterdam: Elsevier/Academic Press Retrieved from http://site.ebrary.com/lib/alltitles/docDetail.action?doclD= 10521171.

Yoon, K. S., Duncan, T., Lee, S. W. Y., Scarloss, B., \& Shapley, K. L. (2007). Reviewing the evidence on how teacher professional development affects student achievement. In Issues \& answers. REL (Regional Educational Laboratory Southwest), (p. 033).

Yue, X. (2019). Exploring effective methods of teacher professional development in university for 21 st century education. International Journal of Innovation Education and Research, 7(5), 248-257. https://doi.org/10.31686/ijier Vol7.lss5.1506.

\section{Publisher's Note}

Springer Nature remains neutral with regard to jurisdictional claims in published maps and institutional affiliations.

\section{Submit your manuscript to a SpringerOpen ${ }^{\circ}$ journal and benefit from:}

- Convenient online submission

- Rigorous peer review

- Open access: articles freely available online

High visibility within the field

- Retaining the copyright to your article

Submit your next manuscript at $\boldsymbol{\Delta}$ springeropen.com 